\title{
KONFLIK INTERNAL PPP DI TENGAH PILKADA JAWA BARAT 2018
}

\author{
Yusa Djuyandi ${ }^{1}$, Sayyid M. Suparman ${ }^{2}$ \\ ${ }^{1}$ Departemen Ilmu Politik, Universitas Padjadjaran, Indonesia \\ 'Email: yusa.djuyandi@unpad.ac.id \\ ${ }^{2}$ Magister Ilmu Politik, Universitas Padjadjaran, Indonesia. \\ 2Email: s.m.suparman27@gmail.com
}

\begin{abstract}
ABSTRAK
Penelitian ini bertujuan untuk menganalisis konflik internal di Partai Persatuan Pembangunan (PPP) di tengah Pilkada Jawa Barat tahun 2018, dengan alasan bahwa konflik di internal PPP yang memuncak sejak kasus Suryadharma Ali telah mengakibatkan adanya perpecahan kepengurusan partai sampai di tingkat daerah, di Jawa Barat perpecahan ini membuat beberapa kader dan fungsionaris partai mendukung pasangan calon gubernur dan wakil gubernur yang di usung oleh partai lain. Metode yang digunakan di dalam penelitian ini adalah kualitatif, dengan data primer bersumber dari hasil wawancara yang berdasarkan teknik purposive, serta data sekunder yang bersumber dari studi literatur, teknik analisis data dilakukan dengan memperhatikan dan memahami, mereduksi dan memilah, melakukan interpretasi, dan melakukan validasi data. Penelitian ini menganalisa bahwa sumber konflik PPP didominasi oleh perebutan suara dan perebutan kekuasaan agar mendapat posisi di kabinet nantinya, kedua pihak juga akhirnya menempuh penyelesaian konflik sesuai dengan prosedur yang tercantum di dalam undang-undang. Proses penyelesaikan konflik yang dilakukan adalah dengan: Pertama kooperatif, yaitu terkait dengan upaya perdamaian di antara pihak yang bertikai yang acap disebut dengan islah. Kedua, degeneratif merupakan gugatan melalui jalur hukum sebagai upaya saling menegasikan satu pihak teradap pihak lainnya. Serta ketiga, kompetitif yakni melalui instrumen muktamar untuk mencari pemimpin baru.
\end{abstract}

Kata Kunci: Konflik internal; PPP; Pilkada.

\begin{abstract}
The purpose of this study is to analyze the internal conflict in the United Development Party (PPP) in the middle of West Java Regional Head Election (Pilkada) in 2018, arguing that the conflict in the internal of PPP which peaked since the case of Suryadharma Ali has resulted in party schism down to local level, in West Java this split made some party cadres and functionaries support the candidate for governor and deputy governor who was carried by other parties. The method used in this research is qualitative, with primary data sourced from interviews based on purposive techniques, as well as secondary data from literature studies, data analysis techniques are carried out by understanding, reducing and sorting, interpreting, and validating data. This research analyzes that the source of the PPP conflict was dominated by votes and power struggles to get a position in the cabinet, the two parties also finally took conflict resolution in accordance with the procedures stated in the law. The process of resolving conflicts is by: Firstly cooperative, which is related to peace efforts between the conflicting parties which are often referred to as islah. Second, degenerative is a lawsuit through legal channels as an effort to mutually negate one party against the other. And third, competitive, namely through the instrument of congress to find new leaders.
\end{abstract}

Keywords: Internal conflict; PPP; Pilkada. 


\section{PENDAHULUAN}

Partai politik (parpol) merupakan pilar utama atas terlaksananya pemerintahan yang demokratis dalam suatu negara (Djuyandi, 2018). Keberadaaan partaipartai politik sebagai bentuk perwakilan dari masyarakat dianggap mampu memberikan pengaruh terhadap perkembangan demokrasi, khususnya dalam ranah politik. Jika perkembangan demokrasi di sebuah negara ditandai pula oleh eksistensi partai politik, maka di Indonesia keberadaan partai politik tidak terlepas dari konflik internal partai. Di awal pra kemerdekaan, perpolitikan Indonesia sudah diwarnai perpecahan partai politik, dari mulai pecahnya Sarikat Islam (SI) menjadi SI Merah, yang kemudian men, jadi Partai Komunis Indonesia (PKI) dan SI Putih yang kemudian menjadi PSII.

Pada era kemerdekaan, konflik dan perpecahan partai mengemuka sejak jatuhnya kekuasaan orde baru, hal ini menunjukan bahwa penggabungan atau fusi partai pada era orde baru di tahun 1973 yang kemudian sudah berjalan selama 25 tahun tidak serta membuat adanya kohesi politik di dalam partai. Mencuatnya konflik internal yang berujung pada perpecahan partai disebabkan olehberbagaialasan, baik yangbersifatideologis atau idealis maupun yang bersifat pragmatis. Dalam hal yang bersifat pragmatis, tidak dipungkiri bahwa adanya kebebasan serta keterbukaan politik memberikan peluang bagi siapapun untuk meraih kekuasaan, dan partai politik mampu memberi peluang bagi siapapun untuk meraih kekuasaan.

Sejak dimulainya kebebasan politik di era reformasi, beberapa kelompok dalam partai politik kemudian melahirkan partai baru, sebagaimana misalnya PDI yang kemudian terpecah menjadi PDI dan PDI Perjuangan, Golkar yang terpecah dan melahirkan Partai Musyawarah Kekeluargaan Gotong Royong (MKGR), Partai Hati Nurani Rakyat (Hanura), Partai Nasdem, dan Partai Gerindra, juga Partai Amanat Nasional (PAN) yang melahirkan Partai Matahari
Bangsa (PMB). Di sisi lain, PPP yang pada masa pemerintahan orde baru menjadi satu-satunya representasi partai Islam, juga di awal reformasi pada akhirnya harus terpecah dan melahirkan beberapa partai baru, seperti PKB, PAN, PBB, PNU, Masyumi.

Isu perpecahan dalam PPP juga terus melanda hingga menjelang masa pilkada 2018, perpecahan PPP ini dilatar belakangi oleh berbagai kronologi yang mengiringi perkembangan partai di tengah keterlibatannya dalam percaturan politik nasional. Konflik internal partai berlambang Ka'bah ini diakui oleh Wakil Sekjen PPP dalam Muktamar Surabaya, Qoyum Abdul Jabar, sudah berlangsung lama (Waskita, 2015). Bermula dari dukungan PPP pada Pilpres 2014, keresahan partai atas status Suryadharma Ali, Ketua Umum PPP yang menjadi tersangka KPK, hingga terusungnya dua nama ketua umum partai yang baru, yaitu Romahurmuziy dan Djan Faridz. Walaupun demikian, KPU secara resmi hanya mengakui PPP di bawah kepemimpinan Romahurmuziy.

Kedua belah pihak, baik kubu Romahurmuziy dan Djan Faridz, berupaya untuk menyelesaikan konflik. Pada mekanisme penyelesaian konflik Partai Politik dapat ditempuh dengan beberapa cara, yaitu melalui AD dan ART internal partai, Mahkamah Partai Politik, dan pengadilan negeri. Banyak pihak memandang konflik yang terjadi di dalam tubuh partai politik di Indonesia merupakan dampak negatif dari perkembangan demokrasi yang tanpa batas.

Kasus konflik dan perpecahan yang menimpa PPP menurut Direktur Eksekutif Lembaga Survei Independen Nusantara (LSIN), Yasin Mohammad, dipicu oleh beberapa alasan: Pertama, kubu internal yang tidak menggunakan sistem demokrasi. Kedua, adanya faksi-faksi di internal partai. Perjalanan politik memang tidak akan terlepas setidaknya dari tiga hal, yaitu 
kekuasaan, kepentingan, dan konflik.

Konflik internal PPP yang disebab kan oleh adanya pertarungan dua kubu dalam memperebutkan kursi ketua umum tidak terhenti pada proses pemilihan ketua, tetapi juga berlanjut pada munculnya perpecahan pengurus di tubuh internal partai. Dalam kaitannya dengan pemilihan kepala daerah, konflik internal dan dualisme kepengurusan memunculkan fenomena ada nya dua rekomendasi yang berbeda dalam pemberian dukungan calon kepala daerah, kondisi ini menimbulkang kebingungan massa pendukung di akar rumput, sebab bagi mereka menjadi tidak jelas perihal pihak mana yang harus diikuti (Undang \& Thamrin, 2016). Bahwa perpecahan kepengurusan internal partai yang terjadi di pusat menurut Nasir (2016) tidak hanya mempengaruhi turunnya kekuatan politik di level nasional tetapi juga di daerah.

Membahas PPP dalam pilgub Jawa Barat menjadi suatu hal yang menarik mengingat adanya perkembangan Islam konservatif di Jawa Barat beberapa tahun ke belakang. Dalam pemilihan Gubernur Jawa Barat (Jabar) tahun 2018, Dewan Pimpinan Wilayah (DPW) PPP Jawa Barat memastikan seluruh unsur PPP mendukung pemenangan pasangan Ridwan Kamil Uu Ruzhanul Ulum (Rindu). Pengusungan Uu Ruzhanul Ulum sebagai pasangan Ridwan Kamil dalam Pilgub Jabar sudah diwacanakan sejak tahun 2017 oleh Ketum PPP, Muhammad 'Romy' Romahurmuziy. Sebelumnya terdapat beberapa nama calon yang diajukan oleh beberapa partai untuk dipasangkan dengan Ridwan Kamil dalam Pilgub Jawa Barat. Beberapa nama tersebut di antaranya adalah Imanul Haq dari Partai Kebangkitan Bangsa (PKB) dan Saan Mustofa dari Partai Nasional Demokrat (Nasdem). Menurut Romy, kedua nama tersebut masih kurang unggul dari kader partainya, Uu Ruzhanul Ulum, yang sudah menjabat selama dua periode sebagai Bupati Tasikmalaya, juga sudah bergerak lama untuk Pilkada Jawa Barat (Wulandari, 2017). PPP pun kemudian berhasil memasangkan kandidatnya tersebut sebagai pasangan Ridwan Kamil pada Pilgub Jabar 2018. Terpilihnya Uu sebagai calon wakil gubernur Jawa Barat merupakan hasil dari proses rekrutmen politik PPP terhadap kadernya.

Meskipun secara kelembagaan PPP berhasil mendorong pencalonan Uu Ruzhanul Ulum sebagai calon wakil gubernur yang mendampingi Ridwan Kamil, namun perpecahan internal PPP ini juga turut mewarnai situasi politik di internal PPP menjelang Pilgub Jawa Barat tahun 2018. Beberapa kader dan pengurus PPP dikabarkan nampak menghadiri kampanye-kampanye beberapa calon kepala daerah yang justeru diusung oleh partai lain. Dukungan yang terpecah akibat konflik internal justru semakin memperkeruh situasi internal partai yang nyatanya juga terpecah di tingkat daerah, situasi pada saat itu juga pada akhirnya membuat PPP masuk dalam kategori partai yang akan kesulitas dalam mendulang suara pada Pemilihan Umum 2019 (Efriza, 2019). Di Provinsi Jawa Barat, PPP pada akhirnya harus kehilangan 6 kursinya di DPRD Provinsi Jawa Barat, dari yang sebelumnya di tahun 2014 mendapat 9 kursi namun tahun 2019 hanya menjadi 3 kursi (Amir, 2019).

Dinamika politik yang terjadi di Jawa Barat menjelang pilkada setiap periodenya selalu menjadi sorotan yang cukup diperhitungkan baik secara regional maupun nasional. Hal ini mempertimbangkan keberadaaan sekitar 31.735.133 jumlah pemilih (KPU Jabar, 2018) yang menjadi faktor penentu dalam pelaksanaan pemilihan umum di wilayah Jawa Barat. Jumlah pemilih tersebut merupakan jumlah pemilih terbanyak dari seluruh wilayah di Indonesia. Warga Jawa Barat juga memiliki karakteristik tersendiri yang harus diperhitungkan dari setiap kader politik yang akan mencalonkan dirinya dalam setiap pemilihan umum yang 
melibatkan para pemilih di Jawa Barat.

Firman Manan, pengamat politik dari Universitas Padjadjaran, sebagaimana dikutip dari Firdaus (2018) memandang bahwa karakter para pemilih di Jawa Barat adalah pemilih yang religius dan tradisional, serta cenderung memilih figur dengan kualitas popularitas yang tinggi. Oleh karenanya, partai-partai politik dan para kadernya yang berkemungkinan besar mendapatkan suara lebih di Jawa Barat adalah mereka yang mampu memenuhi kriteria-kriteria tersebut. Partai berhaluan agama Islam seperti PKS, PKB dan PPP, akan menjadi preferensi utama bagi masyarakat Jawa Barat dibanding partai berhaluan nasionalis, seperti PDI Perjuangan, walaupun tetap bergantung pada setiap calon yang diusung oleh masing-masing partai.

Dalam pencalonan pilgub Jabar 2018, empat partai koalisi yang terdiri dari NasDem, PKB, PPP, dan Hanura memutuskan untuk mengusung Ridwan Kamil dan Uu Ruzhanul Ulum. Hal ini ditegaskan oleh Ketua DPC PPP Kota Bandung, Zaini Shofari. Uu Ruzhanul Ulum yang diusung untuk menjadi orang nomor dua di Jawa Barat merupakan kader PPP. Sosok yang akrab dipanggil "Kang Uu" ini terbilang dekat dengan karakter agamis yang melekat pada PPP. Sebelum menentukan Kang Uu sebagai kandidat, PPP melaksanakan serangkaian proses rekrutmen untuk menentukan bakal calon wakil gubernur Provinsi Jawa Barat. Keterpilihan Kang Uu erat kaitannya dengan kepribadian dirinya sebagai ulama yang dekat dengan kalangan pesantren dan tokoh kyai lainnya. Pamornya tersebut dapat memberikan citra tersendiri bagi warga Jawa Barat yang juga memiliki karakter pemilih yang agamis. Meski secara kelembagaan Kang Uu berhasil mendapat dukungan resmi PPP, tetapi konflik internal mendorong sebagian dari pengurus PPP di Jawa Barat justeru mengambil sikap berseberangan dengan mendukung calon dari partai lain.

Melihat dinamika konflik internal PPP dan isu perpecahan yang terjadi di dalamnya, khususnya dalam menghadapi pemilihan Gubernur dan Wakil Gubernur Jawa Barat tahun 2018, Terlebih studi tentang konflik internal PPP di tengah Pilkada Jawa Barat 2018 adalah sesuai yang belum pernah di teliti oleh penelitian lain. Setidaknya dasar dari argumentasi peneliti telah didasarkan pada studi terhadap penelitian terdahulu yang sejenis, diantara penelitian lain yang sejenis diantaranya telah mengkaji tentang konflik PPP di tingkat pusat sebagai akibat dari keputusan Mukernas II PPP di Bandung yang memberikan sanksi pemberhentian sementara sebagai Ketua Umum kepada Suryadharma Ali (Arawan \& Hasanuddin, 2018). Penelitian lainnya mengkaji tentang adanya upaya penyelesaian konflik PPP melalui berbagai jalur, seperti Mahkamah Partai dan Pengadilan (Al-Ghifari, Hananto, \& Herawati, 2017; Giatama \& Sodiq, 2015) serta membahas tentang faksionalisasi dan konflik internal PPP (Rizkyansyah, Herdiansah, \& Hanan, 2020).

Studi tentang konflik partai dapat dilihat dari perspektif konflik itu sendiri. Dalam bukunya yang berjudul The Functions of Social Conflict, Coser (2012) memandang bahwa keberadaaan konflik adalah normal dan bagian fungsional dari kehidupan manusia. Ia mencoba mengelaborasi level kekerasan dan konsekuensi fungsional dari sebuah konflik. Menurut Coser (2012), konflik bersifat naluriah dan akan selalu terjadi di tengah kehidupan masyarakat. Konflik dapat diartikan sebagai proses yang bersifat instrumental dalam pembentukan, penyatuan dan pemeliharaan struktur sosial. Konflik dapat terjadi ketika perang ataupun dalam kehidupan sehari-hari dan hubungan antar manusia. Baik manusia 
ataupun hewan, keduanya mengalami konflik, namun yang menjadi perbedaannya adalah konflik manusia memiliki tujuan. Konflik sangatlah lumrah terjadi di tengah kehidupan bermasyarakat atau dalam bahasa Coser ia menganggapnya sebagai suatu hal yang "normal".

Bagi Coser (2012), konflik justru erat kaitannya dengan penciptaan integrasi suatu kelompok. Dalam sebuah struktur besar atau kecil, konflik akan menjadi indikator adanya suatu hubungan yang sehat. Teori konflik umumnya disandarkan pada tiga sistem stratifikasi Weber (1949) yaitu: kelas, status dan kekuasaan. Beberapa pendekatan yang digunakan dalam memahami konflik tingkat integrasi masyarakat yang bergantung pada kapasitas untuk mencegah dan meminimalisir konflik sosial, bertentangan dengan Marx yang menganggap konflik akan menciptakan kekuatan kehidupan sosial. Menurut teori Coser, terdapat dua tipe dasar konflik internal: Pertama, konflik yang mengancam dan bertentangan dengan asumsi fundamental yang berhubungan dengan kelompok dan yang tidak.

Sebagian besar ahli teori konflik sosial beranggapan bahwa terjadinya konflik adalah distribusi yang tidak merata dari sumber daya yang langka (unequal distribution of scarce resource) yang menurut identifikas Weber (1949)- adalah kelas, status dan kekuasaan. Sumber dasar konflik lainnya adalah adanya perampasan yang dirasakan oleh sekelompok orang (sense of deprivation) akibat keberadaan kelas. Perasaan tersebut akan menuntun kesadaran suatu kelas untuk menghasilkan konflik dan perubahan sosial.

Sedangkan menurut Ramlan Surbakti (2010), konflik adalah sebuah gejala sosial yang selalu ada dalam setiap lapisan masyarakat, yang berarti konflik tidak dapat dihilangkan. Namun, konflik tetap tidak bisa dibiarkan berkembang tanpa kendali karena akan dapat merusak masyarakat dan negara. Lazimnya konflik seringkali menjadi hal yang tidak dapat dihindari dalam sebuah parpol. Dalam perhelatan demokrasi, persaingan dan perbedaan pendapat merupakan hal yang maklum terjadi. Ia mengategorikan konflik politik dikelompokkan menjadi dua tipe, yaitu: pertama, Konflik positif, yaitu konflik yang tak mengancam eksistensi sistem politik, yang biasanya disalurkan lewat mekanisme penyelesaian konflik yang disepakati bersama dengan konstitusi. Mekanisme yang dimaksud ialah lembaga-lembaga demokrasi, seperti partai politik, badanbadan perwakilan rakyat, pengadilan, pemerintah, pers dan forum-forum terbuka yang lain. Tuntutan akan perubahan yag diajukan oleh sejumlah kelompok masyarakat melalui lembaga-lembaga itu merupakan contoh konflik positif. Kedua, Konflik negatif ialah konflik yang dapat mengancam eksistensi sistem politik yang biasanya disalurkan melalui cara-cara nonkonstitusional, seperti kudeta, separatism, terorisme, dan revolusi. Apabila mayoritas masyarakat memandang lembaga dan struktur yang ada tidak mencerminkan kepentingan umum maka konflik yang disalurkan melalui mekanisme politik justru dipandang sebagai konflik negatif.

Winardi (2011) berpandangan bahwa, manajemen konflik adalah suatu aktivitas yang meliputi beberapa kegiatan, diantaranya: menstimulasi konflik, mengurangi atau menekan konflik, dan menyelesaikan konflik. Stimulasi konflik diperlukan apabila satuan-satuan kerja di dalam organisasi dianggap terlalu lama dalam melaksanakan pekerjaan yang disebabkan rendahnya tingkat konflik. Adapun metode yang perlu dilakukan untuk menstimulasi konflik yaitu: (1) memasukkan anggota yang memiliki sikap, perilaku serta pandangan yang berbeda dengan norma-norma yang berlaku; (2) merestrukturisasi organisasi terutama rotasi jabatan dan pembagian tugas- 
tugas baru; (3) menyampaikan informasi yang bertentangan dengan kebiasaan yang dialami; (4) meningkatkan persaingan dengan cara menawarkan insentif, promosi jabatan ataupun penghargaan lainnya; dan (5) memilih pimpinan baru yang lebih demokratis.

Sedangkan metode penyelesaian konflik yang paling banyak digunakan menurut Winardi (2011) adalah dominasi, kompromis dan pemecahan problem secara integratif.

Konflik yang terjadi di dalam sebuah organisasi seringkali terjadi sebagai akibat dari pertentangan individu atau kelompok dalam mencapai tujuan bersama (Dalimunthe, 2016; Tumengkol, 2016). Dampak yang ditinggalkan konflik di dalam sebuah organisasi akan bergantung pada tata kelola organisasi dan pimpinannya dalam menghadapi dan menyelesaikan konflik yang terjadi. Konflik juga akan memberikan dampak secara langsung maupun tidak langsung terhadap berjalannya suatu organisasi atau dalam konteks ini adalah partai politik.

Dalam pandangan Winardi (2011) bahwa ada beberapa metode yang dapat digunakan untuk menyelesaikan konflik, yaitu metode dominasi, kompromis dan pemecahan problem secara integratif. Metode Dominasi atau penekanan artinya menekan konflik, bukan menyelesaikannya yaitu dengan cara memaksanya tenggelam kebawahpermukaandanmerekamenciptakan situasi yang menang dan yang kalah. Pihak yang kalah biasanya terpaksa memberikan jalan kepada yang lebih tinggi kekuasaannya, menjadi kecewa dan dendam. Dominasi dinyatakan dalam bentuk pemaksaan hingga dengan voting. Metode Kompromi mencoba menyelesaikan konflik dengan menemukan soluis yang bisa menjadi titik tengah/ titik temu dari dua pihak yang berkonflik (win-win solution). Cara ini memperekecil kemungkinan munculnya permusuhan yang mendalam dari kedua belah pihak yang berkonflik, karena tidak ada yang merasa menang atau kalah. Meskipun demikian, jika dipandang dari sudut pandang kemajuan organisasi, bisa jadi ini bukan merupakan metode penyelesaain yang terbaik karena tidak membuat penyelesaian terbaik untuk institusi, ini hanya untuk menyenangkan kedua pihak yang bertikai dan untuk mencegah konflik berkembang ke arah yang lebih besar. Adapun metode Penyelesaian secara intergratif adalah usaha merubah konflik menjadi situasi pemecahan persoalan bersama yang bisa dipecahkan dengan teknik-teknik pemecahan masalah yang umum (Problem Solving). Ini merupakan cara yang terbaik bagi kepentingan institusi, akan tetapi pada kenyataannya sulit diterapkan secara memuaskan karena kurang adanya kemajuan yang sunguh-sungguh atau jujur untuk memecahkan persoalan.

Upaya untuk memecahkan masalah konflik dalam organisasi politik merupakan suatu hal yang memang terkadang sulit dilakukan oleh sebab adanya kepentingan dari individu maupun kelompok, namun mau tidak mau manajemen konflik perlu dilakukan agar organisasi politik tidak mengalami stagnasi pergerakan. Hal yang juga tidak kalah penting dalam penanganan konflik dalam proses demokrasi adalah perlunya pembagian kekuasaan (power sharing) yang dengannya kemudian akan memunculkan perdamaian diantara pihakpihak yang berkonflik (Bormann, et.al., 2019; Carvalho, 2016). Namun hal yang tidak kalah penting dalam upaya mencapai kesepahaman adalah bagaimana antara kedua belah pihak yang berkonflik mampu menyingkirkan persepsi bahwa oposisi atau pihak yang berlawanan adalah tidak hanya salah tetapi juga buruk, kedua persepsi ini perlu ditiadakan dan para pihak yang berkonflik perlu membangun rasionalitas dan kemampuan berpikir mereka (Johnson \& Johnson, 2000; Malhotra \& Carnes, 2008).

Partai memainkan peran penghubung 
yang sangat strategis antara proses-proses pemerintahan dan warga negara. Bahkan banyak yang berpendapat bahwa partai politiklah yang sebetulnya menentukan demokrasi. Partai merupakan pilar yang sangat penting untuk diperkuat derajat pelembagaannya (the degress of institutionalization) dalam setiap sistem politik yang demokratis. Menurut Vicky Randall dan Lars Svasand (2002), sebagai sebuah organisasi yang memiliki aturan dan tujuan formal, parpol dapat terlihat melembaga dengan baik jika parpol tersebut mapan dalam hal pola-pola perilaku, sikap, dan budaya secara terintegrasi. Keberadaan partai politik tidak terlepas dari konflik internal di dalamnya. Di dalam Pasal 32 ayat 1, perselisihan Partai Politik meliputi antara lain: (1) Perselisihan yang berkenaan dengan kepengurusan; (2) Pelanggaran terhadap hak anggota Partai Politik; (3) Pemecatan tanpa alasan yang jelas; (4) Penyalahgunaan kewenangan; (5) Pertanggungjawaban keuangan; dan/atau (6) Keberatan terhadap keputusan Partai Politik

Partai politik adalah organisasi yang bersifat nasional dan dibentuk oleh sekelompok warga negara Indonesia secara sukarela atas dasar kesamaan kehendak dan cita-cita untuk memperjuangkan dan membela kepentingan politik anggota, masyarakat dan membela kepentingan politik anggota, masyarakat, bangsa dan negara, serta memelihara keutuhan Negara Kesatuan Republik Indonesia berdasarkan Pancasila dan Undang-Undang Dasar Negara Republik Indonesia Tahun 1945.

Namun beberapa pandangan skeptis menyatakan bahwa partai politik pada kenyataannya sering kali dijadikan kendaraan politik bagi sekelompok elit yang berkuasa atau memuaskan "nafsu" kekuasaannya sendiri. Menurut Budiardjo (2014), salah satu fungsi partai politik adalah sebagai sarana pengatur dan pengendalian konflik (conflict management). Namun apabila sebuah parpol tidak mampu mengatasi konflikinternalnyamakaparpoldapat dinilai gagal dalam menjalankan fungsi sebagai pengatur konflik. Setidaknya, konflik internal parpol ini akan mempengaruhi beberapa gerak langkah parpol tersebut. Pertama, terganggunya kinerja anggota legislatif. Hal ini disebabkan adanya efek domino dari konflik internal partai yang berdampak pada kinerja kadernya di kursi legislatif, bahkan perpecahan kekuatan fraksi di DPR. Kedua, terganggunya konsentrasi partai parpol dalam menghadapi pilkada. Jika terjadi dualisme kepemimpinan partai, maka dukungan partai dalam pemenangan proses pemilu akan terpecah, yang menyebabkan suara partai sulit terorganisir. Ketiga, hilangnya kepercayaan publik terhadap parpol. Keberadaan konflik akan melahirkan citra buruk partai di mata masyarakat yang akan menimbulkan kerugian bagi partai, juga pelaksanaan program-program partai.

Salah satu ukuran dari pada negara yang demokratis adalah adanya keberadaan partai politik. Sejumlah kajian menguatkan keberadaan parpol sebagai salah datu pilar dari demokrasi. Sebagai institusi demokrasi, partai politik memiliki fungsi, yaitu sosialisasi politik, komunikasi politik, rekrutmen politik, artikulasi kepentingan, partisipasi politik, agregasi kepentingan, serta pembuatan kebijakan (Rosana, 2012; Iskandar, 2016; Djuyandi, 2018).

Dalam penelitian ini, peneliti tertarik untuk membahas perihal konflik internal PPP di tengah Pilkada Jawa Barat 2018 dengan mengkajinya menurut sudut pandang konflik Winardi, Fisher dan Ramlan Subakti. Pemilihan teori ini sendiri didasarkan pada fenomena di lapangan yang memiliki kesesuaian dengan indikator teori.

\section{METODE}

Metode yang digunakan dalam penelitian ini adalah metode kualitatif dengan tipe penelitian deskriptif. Dalam 
penelitian ini, penulis mendeskripsikan tentang bagaimana konflik yang terjadi di dalam Partai Persatuan Pembangunan (PPP) di tengah Pilkada Jawa Barat 2018. Sumber data dalam penelitian ini didapatkan dari data primer dan sekunder, dimana teknik pengumpulan data primer dilakukan dengan melakukan wawancara kepada sejumlah informan. Untuk data sekunder, teknik pengumpulan data dilakukan melalui studi literatur, dengan menggunakan buku, jurnal, media massa dan dokumen-dokumen lain yang membahas dan mengkaji tentang persoalan konflik internal PPP dan kaitannya dengan Pilkada Jawa Barat 2018. Dalam hal teknik pengumpulan data bagi informan maka ditentukan secara purposive, yaitu peneliti menentukan sejumlah kriteria untuk informasi yang diperlukan, diantaranya: memahami konflik internal PPP, memahami kondisi PPPjelang dan pada saat pelaksanaan Pilkada Gubernur Jawa Barat tahun 2018, sampai pada akhirnya menentukan dan mewawancarai Ketua DPC PPP Kota Bandung dan Ketua DPW PPP Jawa Barat sebagai informan penelitian pada tahun 2018. Teknik analisis data dilakukan dengan memperhatikan dan memahami hasil dari wawancara dan studi literatur, kemudian melakukan reduksi data dengan memilah data, melakukan interpretasi data serta melakukan validasi atau menguji keabsahan data. Dalam menguji keabsahan data maka peneliti melakukan proses validasi data dilakukan dengan teknik triangulasi data, dimana peneliti melakukan cross check dari berbagai sumber data yang berkenaan dengan konflik internal PPP jelang Pilkada Jawa Barat 2018.

\section{HASIL DAN PEMBAHASAN Konflik Internal PPP}

Dalam bukunya yang berjudul The Functions of Social Conflict, Coser memandang bahwa keberadaaan konflik adalah normal dan bagian fungsional dari kehidupan manusia. Ia mencoba mengelaborasi level kekerasan dan konsekuensi fungsional dari sebuah konflik. Menurut Coser, konflik bersifat naluriah dan akan selalu terjadi di tengah kehidupan masyarakat. Konflik dapat diartikan sebagai proses yang bersifat instrumental dalam pembentukan, penyatuan dan pemeliharaan struktur sosial. Bagi Coser, konflik justru erat kaitannya dengan penciptaan integrasi suatu kelompok. Dalam sebuah struktur besar atau kecil, konflik akan menjadi indikator adanya suatu hubungan yang sehat.

Sama halnya dengan konflik yang terjadi dalam tubuh PPP konflik adalah sesuatu yang wajar karna PPP sebagai organisasi dan organisme yang tumbuh dan terus terbentuk. Konflik yang terjadi dalam partai tersebut bisa menjadi media untuk membentuk, meyatukan dan memelihara struktur social yang selama ini dibangun oleh PPP. Disamping itu melalui konflik PPP kemudian memperjelas garis batas partai dan membuat anggota yang selama ini belum sepenuhnya membela PPP kemudian bisa berintegrasi ke dalam partai untuk menyelesaikan konflik yang ada.

Menurut Ramlan Surbakti (2010), konflik adalah sebuah gejala sosial yang selalu ada dalam setiap lapisan masyarakat, yang berarti konflik tidak dapat dihilangkan. Namun, konflik tetap tidak bisa dibiarkan berkembang tanpa kendali karena akan dapat merusak masyarakat dan negara. Lazimnya konflik seringkali menjadi hal yang tidak dapat dihindari dalam sebuah parpol. Konflik antara dua kubu PPP adalah sebuah gejala social yang wajar, dimana Romahurmuziy dan Djan Faridz memiliki tujuan dan pandangan yang berbeda sebagaimana yang diungkapkan oleh Fisher, dimana konflik bisa terjadi ketika hubungan kedua belah pihak tidak wajar dan memiliki tujuan yang berbeda. Tetapi kembali lagi kepada pendapat Ramlan Subakti bahwa konflik yang terus dibiarkan berkembang akan dapat merusak tatanan PPP bahkan efek buruknya adalah 
menurunya elektabilitas PPP pada pemilu 2019, artinya konflik ini harus menemukan jalan penyelesaian.

Sebelum konflik benar-benar terjadi tentunya ada sumber yang menjadi pemicu awal. Berdasarkan pendapat Winardi (2011) yang menjadi penyebab terjadinya konflik adalah: (1) Sumber yang harus dibagi; (2) Perbedaan dalam tujuan; (3) Interdependensi aktivitas pekerjaan; (4) Perbedaan nilai yang dianut, dan (5) Gaya individual.

Penelitian ini melihat bahwa adapun yang menjadi penyebab konflik internal di PPP adalah:

1. Sumber-sumber suara untuk Pilpres 2014

Kelompok masyarakat bersaing untuk mendapatkan hasil yang paling besar dari sumber daya yang tersedia. Sumber yang dimaksud adalah sumber suara, sebagaimana yang diketahui konflik PPP diawali denga keputusan sepihak Surya Dharma Ali mendukung kubu Prabowo Hatta pada pemilihan presiden 2014. Saat itu Ketua Umum PPP, Suryadharma Ali (SDA), dianggap oleh sebagian besar Ketua Dewan Pimpinan Wilayah (DPW) PPP dan jajaran elite Dewan Pimpinan Pusat (DPP) PPP telah bertindak melanggar batas Anggaran Dasar (AD)/ Anggaran Rumah Tangga (ART) PPP.

Selain memberikan dukungan kepada pasangan capres-cawapres Prabowo Subianto dan Hatta Rajasa SDA juga menghadiri kampanye paslon tersebut. Beberapa DPW menilai dukungan tersebut melanggar kesepakatan partai dalam Musyawarah Kerja Nasional (Mukernas) PPP di Bandung. Sehingga para pengurus PPP menjatuhkan sanksi kepada SDA. Dalam kaitannya dengan dukungan yang diberikan kepada Prabowo-Hatta.

Fakta dilapangan adalah kubu SDA memaksakan nama Prabowo untuk dimasukkan sebagai calon Presiden dari PPP, sebelumnya nama Prabowo tidak timbul dalam rapat
DPW PPP Se-Indonesia. Namun atas kepentingan kelompok maka kubu SDA mendukung Prabowo dengan cara mengklaim PPP mendukung Prabowo. Perbedaan capres Tahun 2014 membuat konflik PPP memanas hingga Pilpres usai.

Diadakannya Mukernas seharusnya menjadi mekanisme prosedural untuk menyelesaikan masalah di internal partai, namun kenyataannya justru menjadi sumber masalah yang muncul di partai. Forum seperti Mukernas sejatinya merupakan wahana komunikasi politik seluruh stakeholder dalam menyelesaikan persoalan dan merumuskan kebijakan di internal partai, kenyataannya justru berubah menjadi tempat disinformasi dan diskomunikasi antarkader. Pesan tidak tersampaikan secara utuh kepada seluruh anggota partai. Bahkan, pesan dibelokkan menjadi ajang indoktrinasi dan pemaksaan kehendak segelintir elit. Imbasnya cukup fatal, konflik yang terjadi telah merusak soliditas internal partai.

2. Perbedaan dalam tujuan, berlombalomba mendapatkan kursi ketua umum

Organisasi yang cendrung semakin terspesialisasi, semakin pula meraka mengembangkan tujuan-tujuan, tugas-tugas dan personil yang tidak sama. Beberapa organisasi seperti PPP semakin tinggi kedudukan maka akan semakin tinggi kedudukan untuk menjadi di kabinet ditambah dengan beberapa hak istemewa lainnya. Diferensiasi yang demikian seringkali menyebabkan timbulnya konflik kepentingan atau prioritas-prioritas, sekali pun mereka telah sepat tentang tujuan menyeluruh organisasi yang bersangkutan.

Posisi sebagai ketua umum dalam sebuah partai, ditambah partai tersebut mengusung pemerintahan yang sedang berkuasa, maka akan lebih mudah mendapatkan jabatan dalam kabinet. Sehingga terjadilah perebutan kepemimpinan partai antara Romahurmuziy dan Djan Faridz serta perbedaan pilihan 
politik dalam pilkada DKI Jakarta pada tahun 2017.

Namun beberapa pandangan skeptis menyatakan bahwa partai politik pada kenyataannya sering kali dijadikan kendaraan politik bagi sekelompok elit yang berkuasa atau memuaskan "nafsu" kekuasaannya sendiri. Menurut Budiarjo, salah satu fungsi partai politik adalah sebagai sarana pengatur dan pengendalian konflik (conflict management). Namun apabila sebuah parpol tidak mampu mengatasi konflik internalnya maka parpol dapat dinilai gagal dalam menjalankan fungsi sebagai pengatur konflik. Setidaknya, konflik internal parpol ini akan mempengaruhi beberapa gerak langkah parpol tersebut.

Konflik internal partai politik tidak serta merta berujung pada perpecahan atau bahkan fusi dengan kubu lainnya. Hampir setiap partai politik pada akhirnya menemukan proses penyelesaian konfliknya masingmasing sebagai sebuah sistem yang menurut Coser akan terbentuk dengan sendirinya sebagai respon dalam mengatasi konflik.

Pada faktanya konflik PPP bisa digolongkan kepada konflik positif, sebagaimana yang diungkapkan oleh Ramlan Subakti, konflik positif adalah konflik yang tak mengancam eksistensi sistem politik, yang biasanya disalurkan lewat mekanisme penyelesaian konflik yang disepakati bersama dengan konstitusi. Mekanisme yang dimaksud ialah lembagalembaga demokrasi, seperti partai politik, badan-badan perwakilan rakyat, pengadilan, pemerintah, pers dan forum-forum terbuka yang lain. Tuntutan akan perubahan yang diajukan oleh sejumlah kelompok masyarakat melalui lembaga-lembaga itu merupakan contoh konflik positif.

Meskipun demikian konflik PPP melahirkan dampak tersendiri bagi PPP. Pertama elektabilitas PPP terus menurun, Suara PPP pasca konflik mulai merosot, konflik tersebut membuat petaka untuk kekuatan konsolidasi diinternal partai.
Walaupun Ketua Umum DPP PPP Romahurmuziy mengklaim bahwa ada sisi positif dari konflik yang melanda partainya. Romahurmuziy menyebutkan imbas konflik di internal partai, pihaknya semakin rajin melakukan konsolidasi politik di akar rumput partai. Namun klaim konsolidasi yang disuarakan nyatanya tidak memberi efek bagi konsolidasi dan soliditas internal partai. Pilkada serentak di 101 daerah menjadi pembuktian narasi politik yang dibingkai oleh para elit PPP tidak efektif sampai di akar rumput. Ketidaksinkronan antara harapan elit partai di sisi lain dan harapan kader di tingkat bawah merupakan imbas dari adanya jarak komunikasi politik antara elit.

Kedua perpecahan suara pada Pilkada serentak, komunikasi politik yang dilakukan oleh kedua Kubu PPP membuat suara PPP dalam pilkada tahun 2017 lalu terpecah. Karena mereka saling mengkalim didukung oleh organisasi partai PPP. Banyak calon daerah yang menggunakan dukungan dari PPP bermasalah.

\section{Konflik Internal di Tengah Pilkada Jawa Barat 2018}

Perpecahan internal dan adanya dualisme dalam kepengurusan PPP juga turut mewarnai situasi politik di Jawa Barat menjelang Pilgub 2018. Di saat secara kelembagaan PPP mengeluarkan rekomendasi untuk pasangan Ridwan Kamil dan Uu Ruzhanul Ulum (Rindu), namun beberapa kader PPP nampak menghadiri kampanye-kampanye beberapa calon kepala daerah yang diusung oleh partai-partai lainnya, seperti mendukung pasangan Sudrajat dan Syaikhu (Asyik) yang di usung oleh Gerindra dan PKS. Dukungan yang terpecah ini dianggap semakin memperkeruh situasi perpecahan internal partai di tingkat daerah, disamping juga pada saat itu juga turut memberatkan PPP dalam mendorong dukungan bagi pasangan Rindu pada Pilkada Jawa Barat tahun 2018. 
Pengalihan dukungan oleh sejumlah kader PPP di Jawa Barat kepada pasangan calon gubernur dan wakil gubernur bukan hanya diperuntukan bagi pasangan Asyik, namun juga kepada pasangan Deddy Mizwar dan Dedi Mulyadi (2DM). Dalam kegiatan yang diselenggarakan oleh pihak yang menamakan diri mereka sebagai Tim Konspirasi Partai, tim ini kemudian mencetuskan deklarasi yang berisikan dukungan untuk menyukseskan pasangan 2DM dalam Pilgub Jabar 2018. Deklarasi ini memperkeruh suasana dan membuat pertarungan kedua kubu di dalam internal partai menjadi cukup memanas, masingmasing memiliki alasan-alasan yang mereka anggap cukup kuat untuk mengeluarkan dan memberikan dukungan.

Sebagaimana Ketua DPC PPP Kota Bandung, Zaini Shofari, yang mendukung pasangan Rindu memiliki alasan dan keyakinan bahwa dukungannya kepada Kang Uu, bukan hanya soal amanah partai dan Kang Uu sebagai kader PPP, tetapi Uu Ruzhanul Ulum yang diusung oleh PPP untuk menjadi orang nomor dua di Jawa Barat dianggap sebagai sosok yang akrab dan dianggapnya terbilang dekat dengan tokoh agama dan juga sebagai seorang yang agamis. Sedangkan argumentasi kelompok lainnya yang berseberangan dengan kehendak partai dan mendukung pasangan Asyik menilai bahwa pasangan Asyik lebih dianggap merepresentasikan kelompok Islam itu sendiri.

Pada kasus Pilkada di Jawa Barat, meski terjadi perpecahan dalam hal dukungan para kadernya, PPP telah menjadi salah satu kunci yang turut membantu kemenangan pasangan Rindu, dengan Uu Ruzhanul Ulum sebagai kader PPP yang menduduki posisi Wakil Gubernur Jawa Barat. Kemenangan pasangan Rindu dalam Pilkada Jawa Barat di sisi lain juga dianggap oleh Ketua DPC PPP Kota Bandung dan Ketua DPW PPP Jawa Barat mampu menjawab keraguan soal efektivitas
dukunganPPPdalampemenangan pasangan Rindu. Sebagaimana yang diucapkan oleh Ketua Dewan Pimpinan Wilayah (DPW) PPP Jawa Barat "kemenangan ini seolah memastikan seluruh unsur PPP mendukung pemenangan pasangan Rindu dalam Pilkada Jabar 2018. Kasus ini seolah-olah memperlihatkan adanya islah terbatas pada tingkat DPW untuk memilih Uu."

Meski pasangan Rindu memenangkan Pilkada Jawa Barat 2018, namun adanya perpecahan di internal PPP juga membuat suara kader PPP tidak secara optimal terkonsolidasi ke pasangan Rindu. Tidak optimalnya konsolidasi tersebut disebabkan kedua kubu tidak lagi menekankan atas ideologi partai melainkan kepada kepentingan pimpinan dari kedua kubu. Peneliti mengamati bahwa anggota partai yang terbelah tidak lagi solid seperti dulu, tetapi mereka hanya sebatas mengikuti instruksi partai bukan dengan iktikad membangun partai.

Fenomena konflik yang terjadi antara kedua kubu atas masing-masing kepemimpinan Romahurmuziy dan Djan Faridz setidaknya menunjukkan gejala yang berdampak pada perjalanan organisasi partai politik PPP, termasuk dalam hal persoalan pemberian rekomendasi dukungan dalam PilkadaJawaBarat2018. Munculnya deklarasi dari sebagian kader dan fungsionaris PPP di Jawa Barat yang memberikan dukungan kepada pasangan calon kepala daerah lainnya, yaitu pasangan Asyik dan 2DM, menunjukan bahwa konflik internal yang telah mencuat kepermukaan mengarah pada suatu bentuk persaingan yang terbuka dan ingin saling menunjukan kekuatannya. Berdasarkan pada fenomena ini maka dari itu penyelesaian konflik internal PPP sangat dibutuhkan untuk kemaslahatan partai.

\section{Penyelesaian Konflik Internal PPP}

Tahapan penyelesaian konflik yang dilakukan antara Romahurmuziy dengan Djan Faridz melalui tahapan komunikasi politik dan kebijakan Pemerintah Pusat 
melalui Kemenkumham. Tahapan akhir dari konflik sempat dibuktikan melalui tahapan penyelesaian konflik dengan melakukan komunikasi politik, proses ini dilakukan dengan komunikasi yang baik antara Romahurmuziy dan Djan Faridz termasuk dengan pendukung masing-masing kubu. Namun komunikasi politik tersebut sempat tersendat karena Djan Faridz selalu menolak untuk bertemu dengan Romahurmuziy, sedangkan di sisi lain Wakil Presiden Jusuf Kalla telah mengundang Djan Faridz untuk menyelesaikan konflik PPP tersebut.

Konflik internal partai politik tidak serta merta berujung pada perpecahan atau bahkan fusi dengan kubu lainnya. Hampir setiap partai politik pada akhirnya menemukan proses penyelesaian konfliknya masing-masing sebagai sebuah sistem yang menurut Coser akan terbentuk dengan sendirinya sebagai respon adaptasi dalam mengatasi konflik. Jauh sebelum konflik berlangsung menjadi panjang seperti saat ini, Mahkamah Partai PPP juga telah melakukan inisiasi untuk meminimalisir persoalan atas konflik yang mendera di PPP. Mahkamah Partai yang merupakan amanat UU No 2 Tahun 2011 tentang Partai Politik sebagai wadah penyelesaian persoalan di internal partai, namun tidak efektifjuga. Setidaknya, Mahkamah Partai yang didesain sebagai lembaga untuk menyelesaikan masalah di internal partai namun justru dijadikan alat pemukul terhadap pihak lainnya yang tidak sependapat. Setidaknya hal itu yang merasa dirugikan oleh putusan Mahkamah Partai.

Politik dan kebijakan-kebijakan tekhsusnya berkaitan dengan konflik yang terjadi pada PPP adalah hasil dari perilaku kelompok besar yang berusaha menentang bebagai keputusan yang tidak sesuai dengan AD/ART partai. Sebagaimana pendekatan new institusionalisme dimana kelompok yang diri dariaktor-aktorberperan besardalam menyelesaikan persoalan politik. Menurut Boucek (dalam Budiatri, 2018) terdapat tiga pola untuk menyelesaikan persoalan di internal partai, yang diantaranya dapat digunakan oleh PPP, yakni kooperatif, degeneratif dan kompetitif. Pertama, kooperatif yang dimaksud terkait dengan upaya perdamaian di antara pihak yang bertikai yang acap disebut dengan islah. Kedua, degeneratif merupakan gugatan melalui jalur hukum sebagai upaya saling menegasikan satu pihak teradap pihak lainnya. Serta ketiga, kompetitif yakni melalui instrumen muktamar untuk mencari pemimpin baru dalam rangka win win solution. Dalam sudut pandang Dudija (2015), antara kooperatif dan kompetitif akan mewujudkan filosofi keseimbangan "yin - yang", sebagaimana kompetisi akan mampu mendorong motivasi intrinsik untuk terlibat lebih dalam dalam organisasi.

Ketiga instrumen tersebut bertujuan untuk mengakhiri konflik di internal partai. Langkah tersebut juga dimaknai sebagai bentuk dan cara komunikasi antar elit untuk menyelesaikan persoalan yang menghimpit. Jalur islah yang merupakan cara yang paling soft untuk menyelesaikan masalah, nyatanya tidak pernah terwujud. Pemilu 2019 diharapkan akan menjadi Sarana Konsolidasi PPP yang memang tengah mengalami dualisme partai, mengingat juga penurunan suara yang dialami PPP pada beberapa tahun ke belakang (Fazila \& Maimun, 2017).

Bila pun ada upaya untuk mendorong islah yang dilakukan tokoh PPP, seperti $\mathrm{KH}$ Maimoen Zubair, namun upaya tersebut tak pernah terwujud. Komunikasi politik untuk mewujudkan proses islah hanya menjadi materi seruan moral dari para kader, termasuk dari tokoh penting di internal PPP. Instrumen Mahkamah Partai (MP) sebagai lembaga formal yang didesain untuk menyelesaikan perselisihan di internal partai tak bisa berbuat banyak. Keputusan Mahkamah Partai yang seharusnya bersifat absolut bagi pihak-pihak yang bersengketa tidak juga dilaksanakan dengan baik oleh kedua kubu. Masing-masing kubu justru 
melaksanakan muktamarnya sendiri.

Tahapan selanjutnya adalah, kebijakan pemerintah dalam hal ini Kemenkumham melalui hukum untuk menyelesaikan konflik yang ditempuh oleh komponen PPP sejatinya telah berada di ujung proses. Putusan Kasasi MA No 601/2005 menjadi ujung langkah hukum atas kemelut yang menimpainternal PPP. Tahapan penyelesaian damai yang dilakukan oleh komponen PPP melalui jalur hukum dalam persepektif demokrasi merupakan pelaksanaan dari demokrasi konstitusional dimana hukum dan aturan hukum sebagai pemandu dalam menjalankan demokrasi. Semua warga negara harus tunduk pada aturan hukum (rule of law) sebagai penegasan dari komitmen terbentuknya negara hukum (rechstaat) (Budiardjo, 2014).

Upaya penyelesaian konflik internal PPP juga menempuh jalan penyelesaian konflik melalui jalur Pengadilan Negeri. Pada November 2016, Pengadulan Tata Usaha Negara Jakarta menyatakan PPP yang sah adalah kubu Djan Faridz, namun, pada pertengahan 2017 lalu, Pengadilan Tinggi DKI memenangkan banding dari PPP kubu Romahurmuziy. Setelah selesainya Pilkada 2018, Kubu PPP Djan Faridz yang dalam beberapa kesempatan pemilukada tidak sejalan dengan pilihan dukungan Kubu PPP Romahurmuziy, mengajukan adanya pihak mediator untuk menyelesaikan konflik internal di tubuh PPP. Empat pihak yang diharapkan mampu menjadi mediator adalah organisasi-organisasi yang dahulu terlibat dalam pendirian PPP, yaitu Sarikat Islam, PBNU, Parmusi dan Perti. Dari keempat mediator tersebut, salah satu pihak, yaitu Sarikat Islam menyangsikan kompromi antara kedua kubu, walaupun tetap mengapresiasi inisiatif dari Kubu Djan Faridz.

Seluruh tahapan penyelesaian konflik sesuai UU Nomor 3 Tahun 2011 telah dilalui oleh PPP. Penyelesaian konflik internal PPP, baik melalui mahkamah ataupun pengadilan negeri belum terbilang efektif, walaupun ada harapan terselesaikannya Islah dan konsolidasi partai yang lebih baik pada Pilpres 2019 mendatang. Perjalanan penyelesaian konflik yang cukup panjang PPP tetap belum mencapai puncak soliditas partainya. Perpecahan dukungan masih terjadi di beberapa wilayah, termasuk diantaranya di Jawa Barat.

\section{SIMPULAN}

Sumber konflik PPP di dominasi oleh perebutan suara, dan perebutan, dampak dari konflik ini dalam Pilkada Jawa Barat 2018, khususnya pemilihan gubernur dan wakil gubernur, adalah adanya perpecahan dukungan. Disaat secara kelembagaan PPP memberikan rekomendasi dukungan bagi pasangan Rindu, namun pada sisi yang lain beberapa kubu dalam PPP justeru mendeklarasikan dukungan mereka bagi pasangan Asyik dan 2DM.

Meski Konflik PPP menimbulkan perpecahan, termasuk dalam memberikan dukungan politik pada Pilkada Jawa Barat 2018, namun konflik ini masih dianggap sebagai konflik positif karena penyelesaian masalah masih dilakukan melalui mekanisme demokrasi dan hukum. Munculnya konflik internal PPP menjadi sebuah dorongan bagi partai untuk membangun sebuah mekanisme penyelesaian konflik yang dinamis, dengan lebih terbuka dalam melibatkan instrumeninstrumen lainnya di bidang hukum dan pemerintah. Proses penyelesaian konflik yang ditempuh oleh partai-partai politik adalah hasil pembelajaran yang positif bagi partai tersebut dan dapat berpengaruh terhadap peembaharuan demokrasi di dalam internal partai.

Proses penyelesaikan konflik yang dilakukan adalah dengan Pertama kooperatif yang dimaksud terkait dengan upaya perdamaian di antara pihak yang bertikai yang acap disebut dengan islah. Kedua, degeneratif merupakan gugatan melalui jalur hukum sebagai upaya saling menegasikan 
satu pihak teradap pihak lainnya. Serta ketiga, kompetitif yakni melalui instrumen muktamar untuk mencari pemimpin baru dalam rangka win win solution, menempuh jalur hukum, melakukan islah partai. Berdasarkan pada simpulan tersebut maka penelitian ini menyarankan bahwa dalam upaya menyelesaikan konflik internal maka partai politik perlu mengedepankan ketiga hal, yaitu: kooperatif, degenaritf, dan kompetitif.

\section{DAFTAR PUSTAKA}

Al-Ghifari, M.A.D., Hananto, R.B.U.D., \& Herawati, R. (2017). Penyelesaian Konflik Kepengurusan Partai Persatuan Pembangunan Berdasarkan UndangUndang Nomor 2 Tahun 2011 tentang Perubahan atas Undang-Undang Nomor 2 tentan Partai Politik. Diponegoro Law Journal, 6(2), 1-17.

Amir, S. (2019). Konflik Internal Penyebab Perolehan Suara PPP Rontok di Pemilu 2019. Retrieved September 30, 2020, from https://haluan.co/ article/konflik-internal-penyebabperolehan-suara-ppp-rontok-dipemilu-2019-.

Arawan, F., \& Hasanuddin. (2018). Konflik Partai Persatuan Pembangunan (PPP) tahun 2014-2016. JOM FISIP, 5(1), $1-14$.

Asshiddiqie, J. (2005). Kemerdekaan Berserikat, Pembubaran Partai Politik dan Mahkamah Konstitusi. Jakarta: Konstitusi.

Bormann, N.C., Cederman, L.E., Gates, S., Graham, B.A.T., Hug, S., Strøm, K.W., \& Wucherpfennig, J. (2018). Power Sharing: Institutions, Behavior, and Peace. American Journal of Political Science, 63(1), 84-100, https://doi. org/10.1111/ajps.12407.

Budiardjo, M. (2014). Dasar-dasar Ilmu Politik. Jakarta: Gramedia Pustaka Utama.

Budiatri, A.P. (2018). Konflik Internal
Partai Politik di Indonesia Era Reformasi. Jakarta: Pustaka Obor Indonesia.

Carvalho, A.S. (2016). Power-Sharing: Concepts, Debates and Gaps. Janus. NET, e-journal of International Relations, 7(1), 19-32.

Coser, L.A. (2012). The Functions of Social Conflict - The International Library of Sociology. Race, Class and Social Structure. Oxon: Routledge.

Dalimunthe, S.F. (2016). Manajemen Konflik dalam Organisasi. Jurnal Bahas, 27(1), 1-14, https://doi. org/10.24114/bhs.v27i1.5657.

Djuyandi, Y. (2018). Pengantar Ilmu Politik. Depok: Rajawali Press.

Dudija, N.(2015). CooperativevsCompetitive: Filosofi Keseimbangan "Yin-Yang" dalam Hubungan Interdependency. Buletin Psikologi, 23(2), 65-81.

Efriza. (2019). Eksistensi Partai Politik Dalam Persepsi Publik. Politica, 10(1), 17-38.

Fazila, R., \& Maimun. (2017). Dualisme Kepengurusan Dewan Pimpinan Pusat Partai Persatuan Pembangunan Menjelang Pilkada Serentak 2017. Jurnal Ilmiah Mahasiswa FISIP Unsyiah, 2(2), 481-501.

Firdaus, R.F. (2018). Pemilih Jabar tradisional dan religius, siapa Cagub paling berpeluang? Retrieved September 30, 2020, from https:// www.merdeka.com/politik/pemilihjabar-tradisional-dan-religius-siapacagub-paling-berpeluang.html.

Giatama, K.A., \& Sodiq, I. (2015). Sejarah Perjalanan PPP Pasca Orde Baru: Dinamika Politik dalam Mengatasi Konflik Internal Partai. Journal of Indonesian History, 4(1), 32-37.

Iskandar, D. (2016). Keberadaan Partai Politik yang Tidak Diketahui Menelusuri Fungsi Partai Politik di Indonesia Pasca Soeharto. Jurnal Ilmiah Ilmu Pemerintahan, 2(1), 26-37. 
Johnson, D.W., \& Johnson, R.T. (2000). Civil Political Discourse in a Democracy: The Contribution of Psychology. Peace \& Conflict: Journal of Peace Psychology, 6(4), 291-317.

KPU Jabar. (2018). DPT Pilgub Jabar Mencapai 31,73 Juta Pemilih. Retrieved September 30, 2020, from https://jabar.kpu.go.id/2018/04/ dpt-pilgub-jabar-mencapai-3173juta-pemilih/\#: :text=Bandung\%20 $\%$ E $2 \% 80 \% 93 \% 20 \mathrm{Jumlah} \% 20$ p e mi $1 \mathrm{i} \mathrm{h} \% 20 \mathrm{p}$ a d a \% 20 Pilgub,orang\%2C\%20termasuk\%20 $51.514 \% 20$ peny and ang $\% 20$ disabilitas.

Malhotra, N.A., \& Carnes, M.E. (2008). Political Stability Under Uncertainty: Applying Bounded Rationality to the Study of Governance and Civil Conflict. British Journal of Political Science 38(1), 45-64.

Nasir, N. (2016). Electoral Volatility dalam Perspektif Kelembagaan Partai Politik di Indonesia : Sebuah Analisis Hubungan Partai Politik Dengan Konstituen. Jurnal Politik Profetik, 4(1), 37-65.

Randall, V., \& Svasand, L. (2002). Party Institutionalization in New Democracies. Party Politics, 8(1), 5-29.

Rizkyansyah, Herdiansah, A.G., \& Hanan, D. (2020). Faksionalisasi dan Konflik Internal Partai Persatuan Pembangunan. Journal Publicuho, 3(3), 321-336.

Rosana, E. (2012). Partai Politik dan Pembangunan Politik. Jurnal TAPIs, 8(1), 135-150.

Surbakti, R. (2010). Memahami Ilmu Politik. Jakarta: PT. Grasindo.

Tumengkol, S.M. (2016). Dinamika Konflik dalam Organisasi. Jurnal LPPM Bidang EkoSusBudKum, 3(1), 47-63.

Undang, G., \& Thamrin, H. (2016). Konflik dan Integrasi Islam Politik. Al-Fikra: Jurnal Ilmiah Keislaman, 15(2),
$177-231$

Waskita, F. (2015). Politisi PPP Ungkap Kronologi Perpecahan di Partainya. Kompas. Retrieved July 15, 2020, from https://nasional.kompas.com/ $\mathrm{read} / 2015 / 04 / 13 / 0123 /$ Politisi.PPP. Ungkap.Kronologi.Perpecahan. di.Partainya.

Weber, M. (1949). The Methodology of the Social. New York: Free Press.

Winardi. (2011). Manajemen Konflik (Konflik Perubahan Dan Pengembangan). Bandung: Mandar Maju.

Wulandari, F. (2017). PPP Klaim Ada Kadernya yang Layak Dampingi Ridwan Kamil Menuju Jabar 1. Tribunnews. Retrieved July 15, 2020 , from http:/www.tribunnews.com/ nasional/2017/12/20/ppp-klaimada-kadernya-yang-layak-dampingiridwan-kamil-menuju-jabar-1. 